\title{
CLINICAL STUDIES ON THE PULMONARY TUBERCULOSIS COMPLICATED WITH LEPROSY (Report 2)
}

The Results of Mass Examination on Tuberculosis from 1948 to 1959.

\author{
Yoshiko WATANABE
}

National Leprosarium Tama Zenshoen

Mass examination of all leprosy patients admitted to Tama Zenshoen has been conducted once a year from 1948 to 1959. All patients were photofluorographed, and cases with definite or suspicious tuberculous findings on photofluorogram were radiographed. For active cases, medical treatment of any kind was administered, and for inactive cases, periodical check examination was repeated at least twice a year. The results of mass examination were summarized as follows:

1. Prevalence rate of tuberculous findings, including healed lesions increased from $20.5 \%$ in 1954 to $29.4 \%$ 1959. Prevalence of active and inactive tuberculosis was $13.3 \%$ in 1948 , and kept nearly the same level until $1959(13.2 \%)$. Prevalence of active cases was $8.9 \%$ in 1954 , decreased with advances in tuberculosis control, and $3.5 \%$ in 1959 . Bacilli positive cases were decreased from $2.5 \%$ in 1954 to $0.5 \%$ in 1959.

2. Prevarence of active and inactive cases was higher among male than in female. Highest value was obtained in age group 50 to 59 from 1954 to 1956, and in age group over 60 from 1957.

3. Observing by the grade of disease, severe cases including cavitary cases decreased markedly, and slight cases relatively increased.

4. Prevalence of active and inactive cases newly admitted to Zenshoen was nearly the same to that of already admitted patients, but prevalence of active cases were very high among newly admitted cases.

5. Incidence of tuberculosis is decreasing markedly in recent years.

6. Death from tuberculosis showed marked decline since 1952 .

The results mentioned above show that by intensive tuberculosis control, tuberculosis in leprosy patients can be diminished remarkably, and leprosy patients will no more die of tuberculosis. 


\title{
癩に合併せる肺結核症の臨床的研究（第 2 報）
}

\author{
- - 集 団 検䛦 成 績 （昭和 23 年〜昭和 34 年）一
}

渡辺芳子

戦後わが国において，学校，事業所，自治体等の集団 における健康状態を祭知し，文健康の保持増進のため， 殊に結核に関しその早期発見，早期治療,発病予防,環境 衛生等を目的に硉承管理が法の定めによつて行われ，集 団検診が西施されるに至つた。

多磨全生園においても昭和 23 年以来在園者の一斉年次 検診が施行されて今日に及んでいる。昭和 34 年までに 11 回行われた。癩病状の観察と共に, 結核予防会結核研究 所の方々によつて結核検診すなされて来たのである。て れらの資料に基いて廎患者における結核の実態とその推 移を年次を追つて種々の面から検討を加えてみた。既に 本園における第 1 〜筝 3 回の検診成績については小池 ${ }^{(1)}$ の報告があるが，今回は資料の関係から肺結核有病率及 び死亡率についてのみは昭和 $23 \sim 34$ 年（昭和 28 年欠）の 間の推移を，他の諸事項については昭和 $29 \sim 34$ 年の経緯 を見た。なお一般の結核の実態調査 ${ }^{2)}$ 3) と比較考察を加 えてみた。

\section{研 究 方 法}

昭和 $23 \sim 34$ 年の間に，年次每に在園患者全員のX線間 接撮影, 内有所見者及びその疑いあるむのの直接撮影, 結核要医療のものについて検痰, 塗抹及び培養検査を行 つている。排菌の有無は 1 ケ月の間隔で連続 3 回施行の 結果によつて定めた。これら年次別検晾資料をもつて次 に述べる諸事項老蚞索した。

結核有所見率, 有病率（要観祭，要医療, 排菌の割合） の推移, 年令別・有所見・有病率の推移, 昭和 29 年及び 昭和 34 年の性・年令別要指導, 要医療の比較, 集団検診 管理区分の推移，日本結核病学会分類結核病型別推移， 年次別新入園者の有所見率，有病潔，要医療の割合，年 次別新発見及びこの有病率, 要医療の割合, 死亡事の推 移を検討する。

\section{対象および対象の分析}

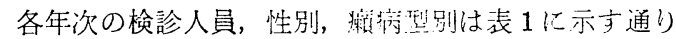
で，年次毎の検䧐総人員はあまり大溠流ないが，各年度 において40〜70名前後の入退琪唾方古る。男于注女子の 二倍よりやや少い。年命階級別人口構成活表 2 !示した

表 1 年次別検查人員、性別、瀨病型別

\begin{tabular}{|c|c|c|c|c|c|}
\hline 次 & 饸查人圓 & 帠 $\mathrm{j}$ & is if & $\mathrm{T}$ 型 & $\mathrm{L}$ 型 \\
\hline 时23年： & 1015 & 623 & 392 & 308 & 707 \\
\hline 24 & $10: 3$ & 645 & 398 & 306 & 737 \\
\hline 25 & 1143 & 733 & 410 & 410 & 733 \\
\hline 26 & 1180 & 760 & $\div 20$ & 413 & $\pi 67$ \\
\hline 27 & 1187 & 767 & 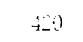 & 423 & 764 \\
\hline 29 & 1199 & 779 & $4=0$ & 334 & 865 \\
\hline 30 & 1204 & 780 & 124 & 331 & 873 \\
\hline 31 & 1204 & 780 & 424 & 327 & 877 \\
\hline 32 & 1196 & 773 & 423 & 260 & 936 \\
\hline 33 & 1196 & 772 & 424 & 268 & 928 \\
\hline 34 & 1180 & 764 & 416 & 248 & 932 \\
\hline
\end{tabular}

表 2 対象の年次別、年令階級別、性別密

\begin{tabular}{|c|c|c|c|c|c|c|c|}
\hline & 昭 29 & 昭 30 & 昭 3 & 昭 32 & 晴 33 & 滪 & 34 \\
\hline 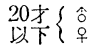 & $\left.\begin{array}{l}23 \\
20\end{array}\right\} \quad 43$ & $\left.\begin{array}{l}17 \\
20\end{array}\right\}$ & $\left.37 \begin{array}{l}16 \\
13\end{array}\right\}$ & $\left.29 \begin{array}{l}19 \\
15\end{array}\right\}$ & $4\left\{\begin{array}{l}17 \\
15\end{array}\right\} \quad 32$ & $\left.32 \begin{array}{l}14 \\
13\end{array}\right\}$ & 27 \\
\hline 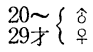 & $\left.\begin{array}{c}124 \\
65\end{array}\right\} 18$ & $\left.\begin{array}{l}106 \\
58\end{array}\right\} 16$ & $\left.64 \begin{array}{c}96 \\
58\end{array}\right\}$ & $\left.154 \begin{array}{c}\frac{-6}{53} \\
5\end{array}\right\} 129$ & $\left.9 \begin{array}{c}79 \\
45\end{array}\right\} 12$ & $\left.24 \begin{array}{l}82 \\
41\end{array}\right\}$ & 123 \\
\hline 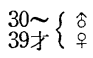 & $\left\{\begin{array}{l}247 \\
105\end{array}\right\} 35$ & $256\} 36$ & $\left.365_{107}^{246}\right\}$ & $\left.353_{102}^{234}\right\}$ & $\left\{\begin{array}{l}217 \\
105\end{array}\right\}$ & $\left\{\begin{array}{r}20 \\
104\end{array}\right\}$ & 310 \\
\hline $\begin{array}{l}40 \sim \\
49 \nsucc\end{array}\left\{\begin{array}{l}\hat{o} \\
+\end{array}\right.$ & $\left\{\begin{array}{r}210 \\
94\end{array}\right\} 301$ & $\left.\begin{array}{l}214 \\
100\end{array}\right\} 31$ & $\left.314 \frac{228}{106}\right\}$ & $334 \div 112\}$ & $221\}$ & $\left\{23 \frac{219}{105}\right\}$ & 324 \\
\hline 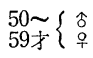 & $\left.\begin{array}{l}115 \\
75\end{array}\right\} \quad 190$ & $\left.\begin{array}{l}119 \\
74\end{array}\right\} 19$ & $\left.93 \begin{array}{c}112 \\
68\end{array}\right\}$ & $\left.180^{1 \frac{120}{6}}\right\} \quad 105$ & $5\left\{\begin{array}{c}143 \\
50\end{array}\right\}$ & $\left.2 \begin{array}{r}142 \\
81\end{array}\right\}$ & 223 \\
\hline 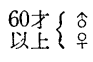 & $\left\{\begin{array}{ll}60 \\
61\end{array}\right\} 121$ & $\left.\begin{array}{l}68 \\
63\end{array}\right\} 13$ & $\left\{\begin{array}{ll}31 & 82 \\
72\end{array}\right\}$ & $\left.154 \begin{array}{c}90 \\
\hdashline\end{array}\right\} 162$ & $2\left\{\begin{array}{l}95 \\
77\end{array}\right\}:-2$ & $\left.\because 2 \begin{array}{l}96 \\
77\end{array}\right\}$ & 173 \\
\hline
\end{tabular}

一例として図 1 に昭和 29 年のもの示したが，全年度に おいて20才以下の若年層は少く，最む多いのは昭和29～ 31年においては30〜39才である方，昭和 32 年以後は40〜 49才が多い。癩病型別には両者の出率が類結故型( $\mathrm{T}$ 型) 
図 1 年令階級別、性別人口構成（昭和 29 年）

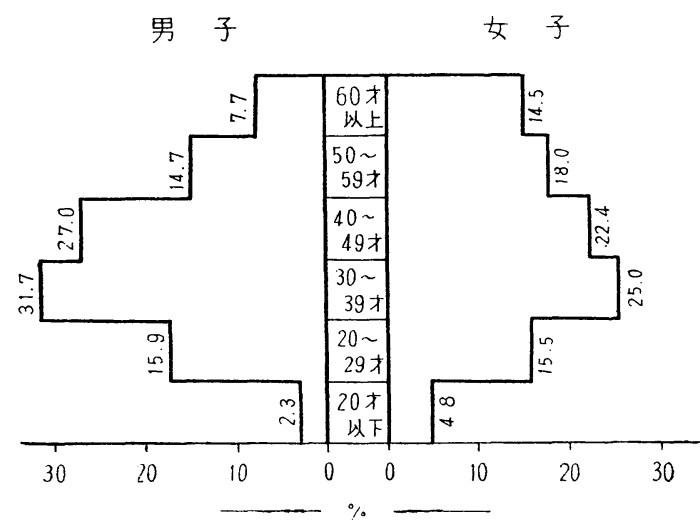

$21.0 \%$ 30.0\%, 瀬腫型 (L 型) 79.0\%〜 70.0\%である。

$\mathrm{X}$ 線検査上, 胁膜炎治瘾，石灰化せるものをも有所見 に含めた。有所見のうち治瘺所見の屯のを除き有病（要 指導で，要観察と要医療に分つ）とし，結核管理区分は 検診年次により相違があり管理の実際に即して変更され て来た。全体を昭和 31 年以降の管理区分に修正統一し た。

結核の管理に必要な活動性分類について島尾 ${ }^{(4)}$ は「指 導区分は患者の医療面，生活面での取り扱い方を決めた あので感染防止という観点から区分されていない。集団 の管理を行つてゆく場合感染防止策をとる必要がある。 患者の分類を考える場合に，乙の感染防止という公衆衛 生的な考え方をとり入れたのが活動性分類である。」と 述べている。胸部X線所見の結核病型分類は始めから岡 分類によつてなされたが昭和 34 年日本結核病学会病型分 類委員会 ${ }^{(5)}$ の決定した分類は，従来の多くの分類よりあ 簡明で，集団検診に用いるに適した活動性分類を加味し たものであり，昭和34年の検診より用いられている。本 研究の結核病型にはこれを用い，昭和 33 年までの岡分類 をてれに相当する本病型に改めて検討した。本分類を以 後日結学会分類と記載する。

\section{成績並びに考案}

昭和 23 年一斉検診以来，感染性患者は一忘の隔離がな され，新入園者のツベルクリン反応検査，陽転者の管 理，㓌性者に対する B C G 注射(昭和 $23 \sim 29$ 年の間)，昭 和 30 年よりツ反応陽転者に I N H の予防内服要医療者の 化学療法施行等一連の結核対策がとられて園内から結核 患者をなくしようとする努力がつづけられて来た。てれ ら事業の成果の有無が11回にわたる検診の成績からうか
がい知る事が出来よう。

表 3 年次別検診成績（この 1 ）

\begin{tabular}{|c|c|c|c|c|c|c|}
\hline 年 & 次 & 昭 和 23 & 24 & 25 & 26 & 27 \\
\hline 有 㽶 & & 136 & 149 & 165 & 172 & 166 \\
\hline 有病 & 率 & $13.3 \%$ & $14.3 \%$ & $15.5 \%$ & $14.70^{\circ}$ & $14.5 \%$ \\
\hline
\end{tabular}

表 3 年次別検診成績（その 2 )

\begin{tabular}{|c|c|c|c|c|c|c|c|c|}
\hline & 有所見 & 90 & 有 病 & $\ddot{c}^{\circ}$ & 要医乫 & 90 & 排 荣: & 96 \\
\hline 昭和 29 . & 245 & $20.5 \%$ & 188 & $15.8 \%$ & 106 & $8.9 \%$ & 30 & 2.590 \\
\hline 30. & 282 & $22.5 \%$ & 193 & $14.3 \%$ & 101 & $8.3 \%$ & 30) & 2.5 .0 \\
\hline 31. & 281 & $23.4 \%$ & 191 & $15.9 \circ^{\circ}$ & 86 & 7.190 & 25 & $2.10^{\prime}$ \\
\hline 32. & 331 & $27.7 \%$ & 194 & $16.2,0$ & 55 & $4.60^{\circ}$ & 20 & 1.7 .0 \\
\hline 33. & 332 & $27.8 \%$ & 179 & $14.3 \%$ & 55 & 4.60 & 14 & $1.2 \%$ \\
\hline 34. & 346 & $29.4 \%$ & 155 & $13.2,8$ & 36 & $3.5 \%$ & 6 & 0.5 \\
\hline
\end{tabular}

結核有所見，有病，要医療及び排菌の割合は表 3(こ の 1 ，その 2) 及び図 2 に示す如くで，有所見率は次第 飞増加し，昭和 29 年 20.5 力か昭和 34 年 $29.4 \%$ となり，有 病沎は昭和 23 年 13.3 .5 より 16.2 .0 となり，昭和 32 年より 減少，昭和 34 年13.2\%となつた。要医療の割合は昭和 29 年106, (8.9\%) 排菌者30 (2.5\%) が年次每に減少, 餎

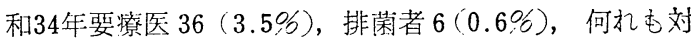
全在園者に隇少した。日本の結核奏態調査では排菌の割 合は昭和 33 年 $0.7 \%$ (対人口) だある。（これは 1 回の㖮 痰成績であるが，本園患者においては 1 ケ月間隔 3 回梚 痰の結果により定めた。）年令別に有所見，有病，要医 療の割合の推移を昭和 29 年, 昭和 34 年について見たもの を図 3 に示した。雨年度の比較では60才以下有病率は做 少し殊に若年層及び50～59才の層において著明であり， 要医療は同様60才以下に打いて著しく渽じている。全 般的にみて 20 才以下は極めて少いか父は全く無い。最引 多い年令層は昭和 $29 \sim 31$ 年には50〜 59 才であり，昭和 32 〜34年には60才以上であつて，最近高年層に多くなる傾 向を示す。小池 ${ }^{(1)}$ の報告した昭和 $23 〜 25$ 年の検䛦成績で は50〜59才が最む多い。

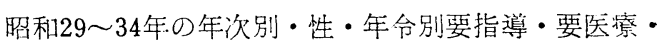
要観祭の割合を表 4 亿示した。要医療は各年令層におい て年次简:に男女共滅少の傾向が見うれるが，60才以上は 一時増加ああり減少は目立たない。要観察は30才以上は 稍增加の傾向が見られる（要医療の軽快による）。要指導 (有病率) は20才層及び50才層が著明に減少し，60才以 上は昭和 32 年迄増加の傾向で以後減少しているが，昭和 34 年においてなお昭和 29 年よりやや多い。何れの率む男 
図 2 年次別集団検䧐成績

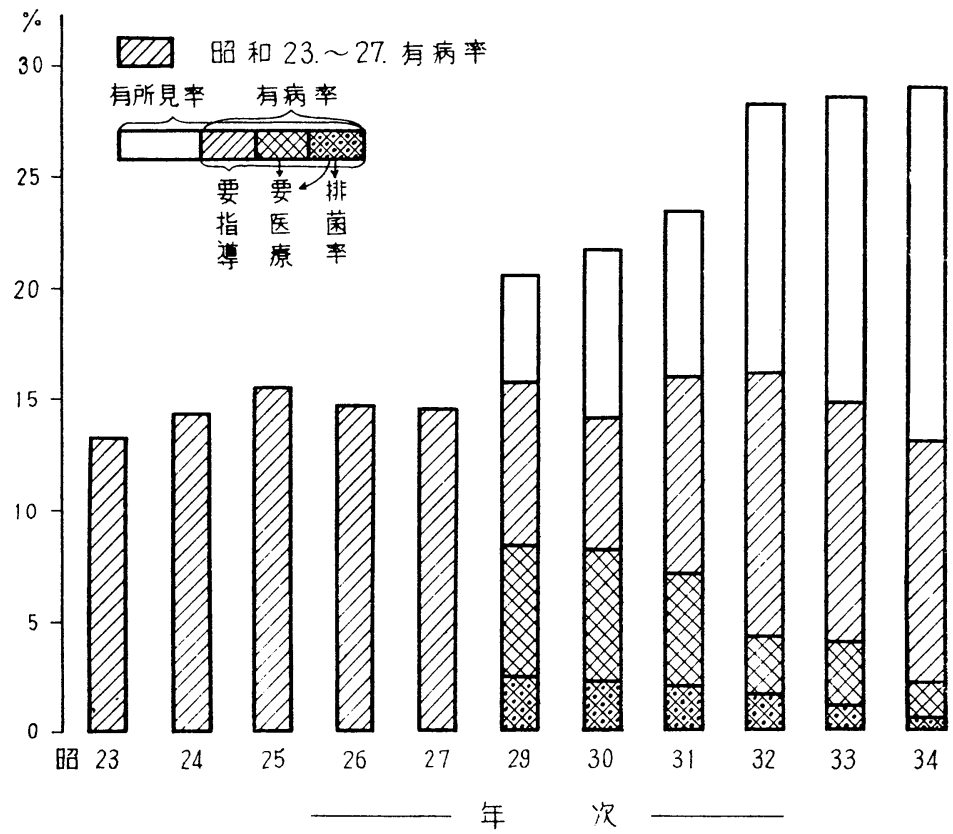

図 3 年命別・結核有所見率・有病率 昭和 29 年および 34 年について

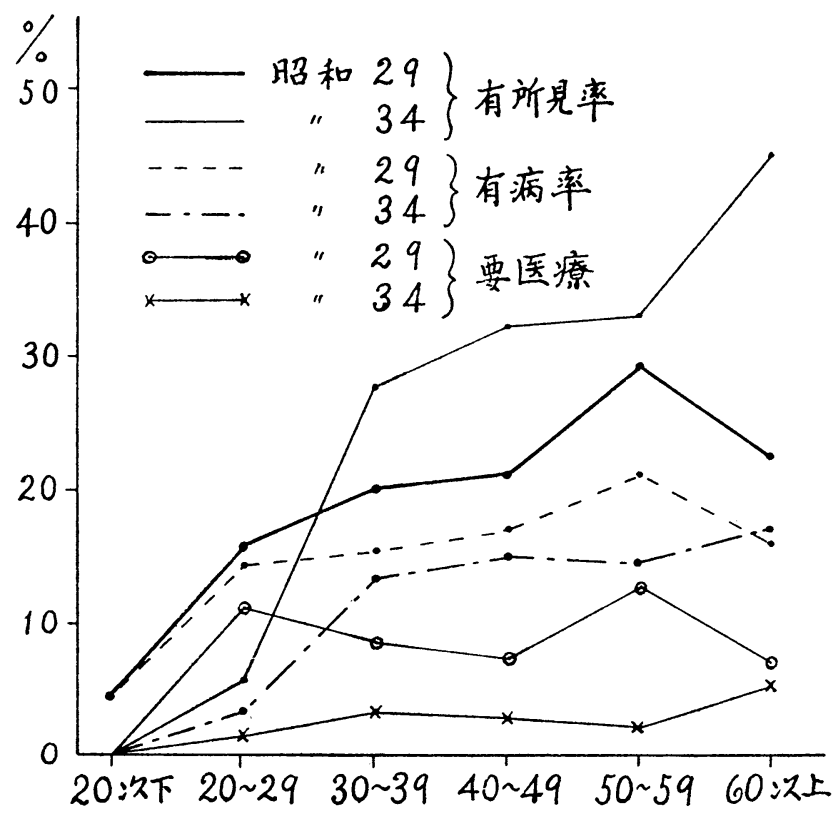

年令 
表 4 年次別・性・年令階級別肺結核要医療率・要観察率・要指導率（在園人口対）

\begin{tabular}{|c|c|c|c|c|c|c|c|c|c|c|c|c|c|c|c|c|c|c|}
\hline & & 要 & 猤 & & 療 & & & 要 & 観 & & 察 & & & (計) & 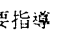 & （住 & & \\
\hline 年_— 次 & 昭 29 & 30 & 31 & 32 & 33 & 34 & 昭 29 & 30 & 31 & 32 & 33 & 34 & 昭 29 & 30 & 31 & 32 & 33 & 34 \\
\hline 総 & 8.9 & 8.3 & 7.1 & 4.6 & 4.6 & 3.5 & 6.9 & 6.0 & 8.8 & 11.6 & 9.7 & 9.7 & 15.8 & 14.3 & 15.9 & 16.2 & 14.3 & 13.2 \\
\hline 男 & 10.8 & 10.1 & 9.1 & 6.2 & 5.6 & 3.7 & 6.9 & 8.1 & 9.7 & $12: 9$ & 10.9 & 12.1 & 17.7 & 18.2 & 18.8 & 19.1 & 16.5 & 15.8 \\
\hline 女 & 5.2 & 5.2 & 3.5 & 1.7 & 2.8 & 1.4 & 6.7 & 6.8 & 6.9 & 9.2 & 9.5 & 6.9 & 11.9 & 12.0 & 10.4 & 10.9 & 12.3 & \\
\hline $0 \sim 19 才$ & 0 & 2.7 & 3.4 & 0 & 0 & 0 & 0 & 2.7 & 0 & 0 & 0 & 0 & 0 & 5.4 & 3.4 & 0 & 0 & 0 \\
\hline 男 & 0 & 5.9 & 6.2 & 0 & 0 & 0 & 0 & 5.9 & 0 & 0 & 0 & 0 & 0 & 11.8 & 6.2 & 0 & 0 & 0 \\
\hline 女 & 0 & 0 & 0 & 0 & 0 & 0 & 0 & 0 & 0 & 0 & 0 & 0 & 0 & 0 & $\begin{array}{l:l}0 & 0\end{array}$ & 0 & 0 & 0 \\
\hline $20 \sim 29 才$ & 11.1 & 12.2 & 9.1 & 5.4 & 2.4 & 1.6 & 4.2 & 3.3 & 4.1 & 4.7 & 0 & 1.7 & 15.3 & 15.5 & 13.2 & 10.1 & 2.4 & 3.3 \\
\hline 男 & 12.1 & 14.2 & 10.4 & 6.6 & 2.5 & 2.4 & 0.8 & 0 & 3.1 & 3.9 & 0 & 1.2 & 12.9 & 14.2 & 13.5 & 10.5 & 2.5 & 3. \\
\hline 女 & 9.2 & 8.6 & 6.9 & 3.8 & 2.2 & 0 & 7.7 & 8.6 & 5.2 & 5.6 & 0 & 2.4 & 16.9 & 17.2 & 12.1 & 9.4 & 2.2 & 2.4 \\
\hline $30 \sim 39 \Varangle$ & 11.9 & 6.9 & 6.2 & 3.6 & 4.3 & 3.2 & 3.2 & 7.4 & 7.7 & 12.7 & 12.2 & 9.9 & 15.1 & 14.3 & 13.9 & 16.3 & 16.5 & 13.1 \\
\hline 昌 & 10.5 & 8.6 & 8.1 & 5.1 & 4.2 & 2.9 & 6.8 & 7.8 & 6.9 & 3.7 & 14.2 & 11.6 & 17.3 & 16.4: & 15.0 & 18.8 & 18.4 & 14.5 \\
\hline 女 & 3.8 & 2.7 & 1.9 & 1.0 & 4.8 & 3.9 & 6.7 & 6.0 & 3.7 & 9.8 & 7.6 & 7.3 & 10.5 & $8 . T^{\prime}$ & 5.6 & 10.8 & 12.4 & 10.6 \\
\hline $40 \sim 49 x$ & 7.6 & 8.0 & 8.4 & 4.4 & 4.0 & 2.5 & 9.6 & 8.6 & 10.5 & 13.2 & 12.4 & 12.6 & 17.2 & 16.6: & 13.9 & 17.6 & 16.4 & 15.1 \\
\hline 男 & 9.1 & 9.3 & 10.5 & 5.7 & 5.0 & 2.7 & 10.0 & 9.4 & 10.5 & 14.5 & 12.2 & 14.5 & 19.1 & 18.7 & 21.0 & 20.2 & 17.2 & 17. \\
\hline 女 & 4.3 & 5.0 & 3.8 & 1.8 & 2.0 & 1.9 & 5.3 & 7.0 & 10.4 & 10.7 & 12.7 & 8.6 & 9.6 & 12.0 & 14.2 & 12.5 & 14.7 & 10.5 \\
\hline $50 \sim 59 才$ & 12.6 & 12.0 & 7.8 & 6.2 & 4.9 & 3.1 & 8.4 & 8.7 & & 8.7 & 10.7 & 10.3 & 21.0 & 20.7 & 16.6 & 14.9 & 15.6 & 13.4 \\
\hline 男 & 15.7 & 13.5 & 9.8 & 8.7 & 7.0 & 4.2 & 8.7 & 10.9 & 10.7 & 9.5 & 8.4 & 14.1 & 24.4 & 24.4 & 20.5 & 18.2 & 15.4 & 18.3 \\
\hline 女 & 8.0 & 8.1 & 4.4 & 1.4 & 1.3 & 1.2 & 8.0 & 6.8 & 5.9 & 7.3 & 13.0 & 3.7 & 16.0 & {$\left[4.9^{i}\right.$} & 10.3 & 8.7 & 14.3 & 4.9 \\
\hline 60 才以才 & 6.6 & 6.1 & 4.5 & 4.9 & 8.1 & 5.2 & 9.8 & 107 & 13.5 & 17.9 & 12.3 & 12.7 & 16. & 16.8 & 18.0 & 22.8 & 20.4 & 17.9 \\
\hline 男 & 10.0 & 7.4 & 6.1 & 7.8 & 11.6 & 8.3 & 10.0 & 11.7 & 17.1 & 22.2 & 14.1 & 15.6 & 20.0 & 19.1 & 23.2 & 30.0 & 25.7 & 23.9 \\
\hline 女 & 3.3 & 4.8 & 2.8 & 1.4 & 3.9 & 1.3 & 8.2 & 9.5 & 9.7 & 12.5 & 9.1 & 9.0 & 11.5 & 14.3 & 12.5 & 13.9 & 13.0 & 10.3 \\
\hline
\end{tabular}

図 4 性・年令別・要指導・要医療の割合

昭和 29 年障

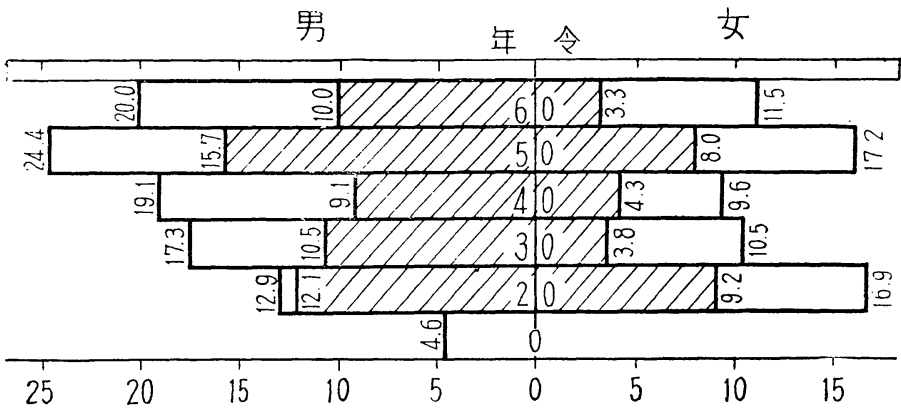

昭和 34 年度

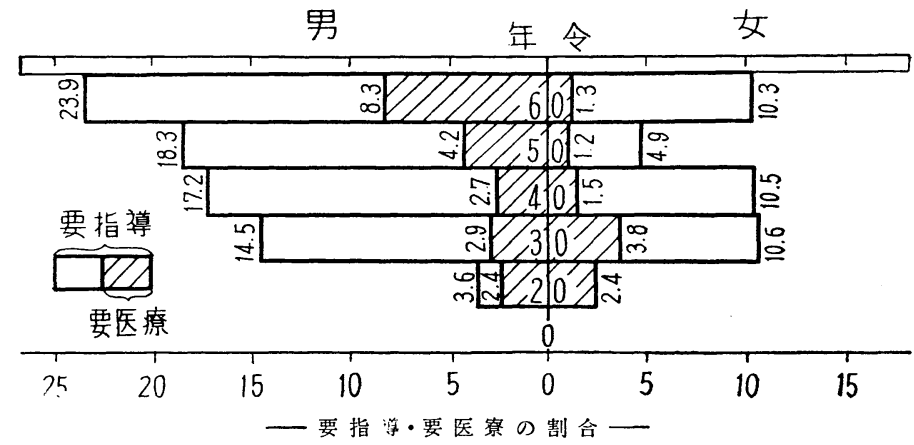


子は女子より多いてとは一般と同様である。性,年令別, 要指導, 要医療, 要観察の割合を昭和 29 年及び 34 年につ いて比較し困 4 亿示した。

日本の結核実態調查昭和 28 年 ${ }^{(2)}$ と本園患者昭和 29 年の 状態を比較するに，有所見率は都市部の $19.8 \%$ （全地区 15.7\%)に近似し，有病率は本園患者 $15.8 \%$ に対し一般は 都市部8.1\%(全地区5.9\%)である。さらに，実態調查昭 和 28 年 $\rightarrow 33$ 年 ${ }^{(2)}(3)$ の推移々, 本園患者昭和 29 年 $\rightarrow 34$ 年の 推移の成績を比較すると, 前者における肺結核要医療は $3.1 \% \rightarrow 3.2 \%$ あ゙ってあまり変りはないが，後者におい ては $8.9 \% \rightarrow 3.5 \%$ と艺減少は二分の一以下になつてい る。有病率は前者は $5.9 \% \rightarrow 4.7 \%$ となり, 後者は $15.8 \%$

表 5 肺結核有所見率、有病率

要医療、要観察の一般との比較

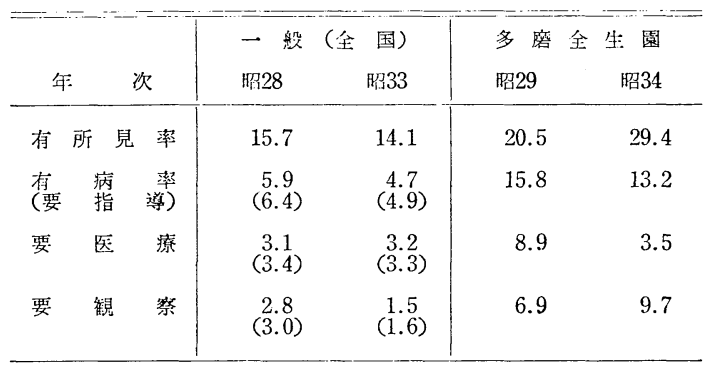

一般の（）内は全絬核を示す

図 5 年令別要指導及び要医療の割合 一般の実態調查と癩の結核との比較

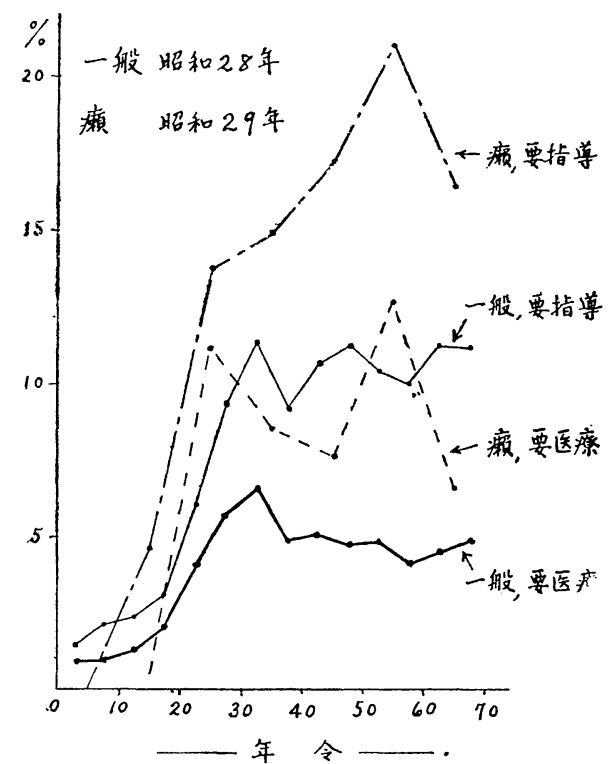

$\rightarrow 13.2 \%$ となる。両者の年令階級別人口構成に相当の差 があるので, これを年防階級別に, 要指導(有病率), 要 医療を比較して図 5 に示した。一般の昭和 28 年と癩患者 の結核の昭和 29 年では，要医療は 20 才以上を除き各年令 層において，癩患者は一般より2.0 7.0\%高率で, 1.5 2 倍に相当し，要指導も同様に癩患者が $5 \sim 11 \%$ 高く 1.5 2倍に当る。即ち年令別にみても明らかに癩の結核 が一般より高率である事を示した。然るに上述の如く 両者 5 年後の要医療の減少の制合は明らかに本園患者に おいて著明であつて，両者の比較を図 6 亿示したが， 一般より高率であつたものが反対に低率となり減少の 著しい事が明らかである。要医療は両者共に壮年次下の 年令層に減少が著明で，高年層においては多くなつてい る。

結核要指導の管理区分の推栘は表 6 及び図 7 亿示す如 く, A (要療養) は, 昭和 29 年 $66,35.1 \%$ で以後漸減し

表 6 年次別、管理区分の推移

\begin{tabular}{r|r|r|r|r|r}
\hline & 要指導 & $\mathrm{A}$ & $\mathrm{B}$ & $\mathrm{C}$ & $\mathrm{D}$ \\
\hline 昭29 & 188 & $66(35.1 \%)$ & $42(22.4 \%)$ & $75(39.9 \%)$ & $5(2.7 \%)$ \\
30 & 193 & $59(30.3 \%)$ & $41(21.2 \%)$ & $85(44 \%)$ & $8(4.2 \%)$ \\
31 & 191 & $24(12.6 \%)$ & $48(25.2 \%)$ & $101(53 \%)$ & $18(9.4 \%)$ \\
32 & 194 & $18(9.3 \%)$ & $34(17.5 \%)$ & $91(47 \%)$ & $51(26.3 \%)$ \\
33 & 179 & $14(7.8 \%)$ & $14(7.8 \%)$ & $85(47.4 \%)$ & $66(36.9 \%)$ \\
34 & 155 & $8(5.2 \%)$ & $13(8.4 \%)$ & $71(45.8 \%)$ & $63(40.6 \%)$ \\
\hline
\end{tabular}

図 6 年令別要指導及び要医療の割合 一般の実熊調查と相の結核との比輍

一般昭和 33 年

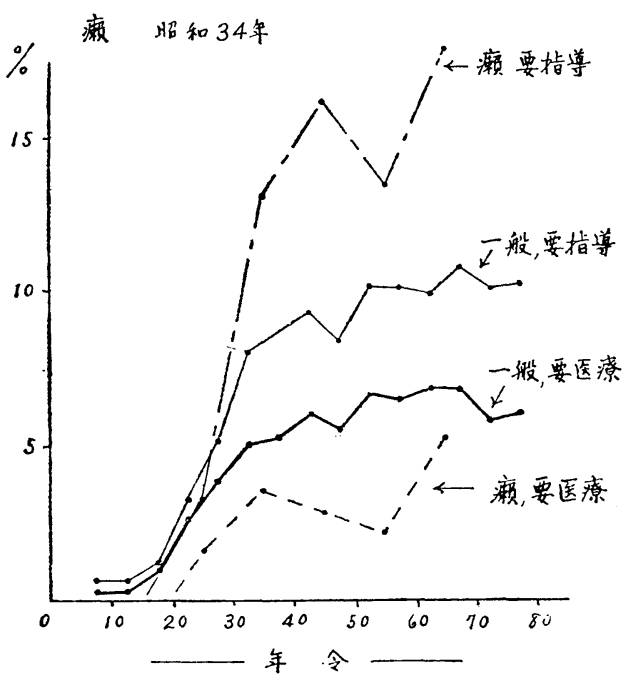


図 7 年次別集団検診管理区分の推移

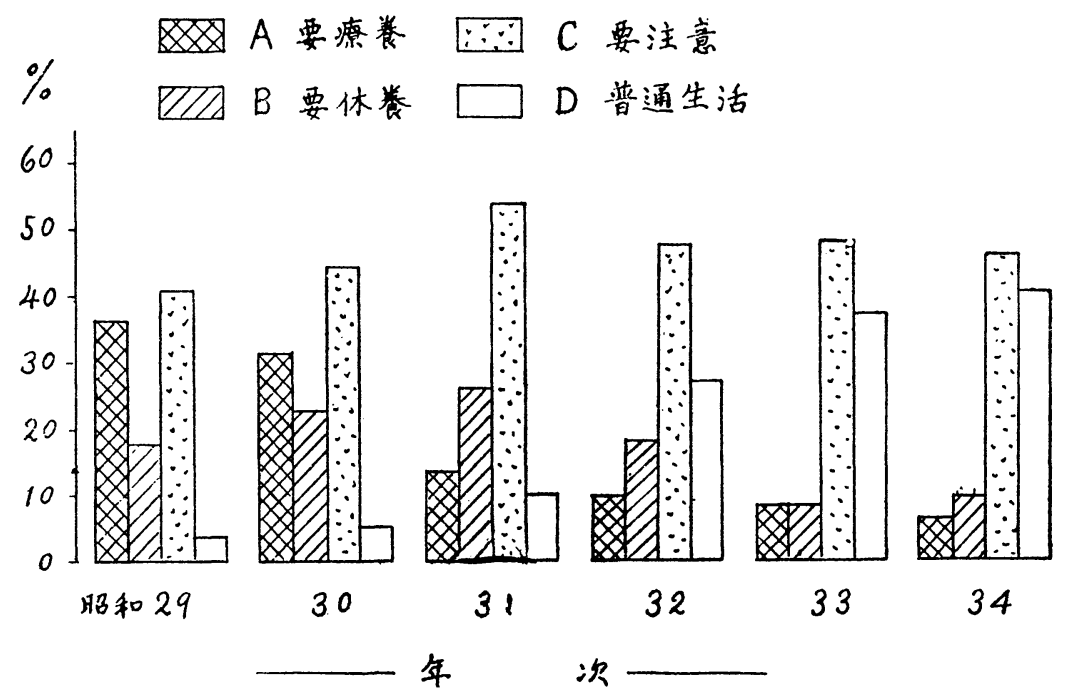

表 7 年次別、日結学会分類病型別推移

\begin{tabular}{|c|c|c|c|c|c|c|c|c|}
\hline & 有所見 & I + II 型 & 型 & 型 & 型 & PL & & $\mathrm{P}$ \\
\hline 昭 29 & 245 & $22(9.0 \%)$ & $72(29.4 \%)$ & $92(37.6 \%)$ & $58(23.8 \%)$ & $1(0.4 \%)$ & & \\
\hline 30 & 282 & $22(7.8 \%)$ & $71(25.2 \%)$ & $99(35.1 \%)$ & $90\left(32.00^{\circ}\right)$ & & & \\
\hline 31 & 281 & $19(6.8 \%)$ & $54(19.2 \%)$ & $115(41.0 \%)$ & $93(33.0 \%)$ & & & \\
\hline 32 & 331 & $14(4.2 \%)$ & $34(10.4 \%)$ & $141\left(42.4, c^{\prime}\right)$ & $140\left(42.39 b^{\prime}\right)$ & $1(0.3 \%)$ & & $1(0.3,0)$ \\
\hline 33 & 332 & $10(3.0 \%)$ & $24\left(7.20^{\circ}\right)$ & $139(42.0 \%)$ & $157(47.396)$ & $1(0.3 \%)$ & $1 \times(2)$ & $(0.3 \%)$ \\
\hline 34 & 349 & $5(1.4 \%)$ & $12(3.4 \%)$ & $127(36.4, \%)$ & $203(58.2 .0)$ & & $2+(2)$ & $\left(0.6 ? 0^{\circ}\right)$ \\
\hline
\end{tabular}

て，昭和 34 年 $8,5.2 \%$ となり，B（要軽業）は昭和 31 年 以降に減少しはじめ，C（要注意）は炤和 29 年より昭和 31年まで上景をたどり以後減少の傾问を示し，D（普通 生活, $\mathrm{D}_{3}$ 除く）は年次毎に增加著明であつて病状の軽 快傾向を如実に示している。

これ更に有所見者について日結学会分類結核病型別 にこの推移を見たのが表 7 及び図 8 で，I 型（広汎空洞 型) 及びII 型(非広汎空洞型)はその数が少いので，合せ てI+II 型とした。これは炤和 34 年には昭和 29 年の数の $1 / 6$ 亿減じ， III型(非空洞不安定型)は昭和29年72例29.4\% より昭和 34 年 12 例 $3.4 \%$ 亿著減し, IV 型（非空洞安定型） は増減があまり著しくない。V型(治瘾型)は次第に増加 して病状の全般的に軽くなつて来ていることが目立つ。
年次別にみた新入園者の結核有所兒，有病，要医療の 割合は表 8 に示す如くで，乙れを平均して，有所見率は 在園者よりやや低いが，有病はほぼ同率である。然るに 要医療のものの占める割合は多く $11.7 \%$ (対新入園者) で，その上A (要療養) が新入園結核要指導の $40.3 \%$ で ある事は注意さるべき点である。

年次別にみた新発見の状況をみると，表 9 に示す如く で，全般的な傾向は要医療及で有病率が著明に減少して いる。

本園患者の肺結核による死亡率は昭和23～34年につい て表10に示す如く, 昭和 27 年以後は著明に減少してい る。全結核の死亡率は昭和 29 年以降減少著明である。 
表 8 年次別新入園、有所見、要指導、要医療

\begin{tabular}{|c|c|c|c|c|c|c|c|c|c|}
\hline & & & 昭 29 & 昭 30 & 昭 31 & 昭 32 & 昭 33 & 昭 34 & 平 \\
\hline 有 & 所 & 見 & $14(37.8 \%)$ & $6(12.0 \%)$ & $2(4.5 \%)$ & $6(13.3 \%)$ & $6(15.4 \%)$ & $7(20.6 \%)$ & $\frac{41}{6}-(16.5 \%)$ \\
\hline 要 & 指 & 導 & $13(35.2 \%)$ & $6(12.0 \%)$ & $2(4.5 \%)$ & $5(11.1 \%)$ & $6(15.4 \%)$ & $5(14.7 \%)$ & $\frac{37}{6}\left(14.99^{\prime}\right)$ \\
\hline 要 & 医 & 暆 & $9\left(24.3 \%^{\circ}\right)$ & $6(12.0 \%)$ & $1(2.3 \%)$ & $3(6.7 \%)$ & $6(15.4 \%)$ & $4(11.8 \%)$ & $\frac{29}{6}(11.7 \%)$ \\
\hline \multicolumn{3}{|c|}{ 年間新入園者 } & 37 & 50 & 44 & 45 & 39 & 34 & $\frac{249}{6}$ \\
\hline
\end{tabular}

表 9 年次別、新発見発生率

\begin{tabular}{|c|c|c|c|c|c|c|c|c|}
\hline & & & 昭 29 & 昭 30 & 昭 31 & 昭 32 & 昭 33 & 昭 34 \\
\hline 有 & 所 & 見 & $49(4.1 \%)$ & $28(2.3 \%)$ & $9(0.8 \%)$ & $47(3.9 \% 6)$ & $20(1.7 \%)$ & $22(1.9 \%)$ \\
\hline 要 & 指 & 遒 & $43(3.6 \%)$ & $14(1.6 \%)$ & $5(0.4 \%)$ & $15(1.3 \%)$ & $10(0.8 \%)$ & $1(0.08 \%)$ \\
\hline 要 & 医 & 療 & $23(1.9 \%)$ & $8(0.7 \%)$ & 0 & $4(0.3 \%)$ & $5(0.4 \%)$ & $2(0.1796)$ \\
\hline
\end{tabular}

図 8 年次別日結学会分類病型別推移
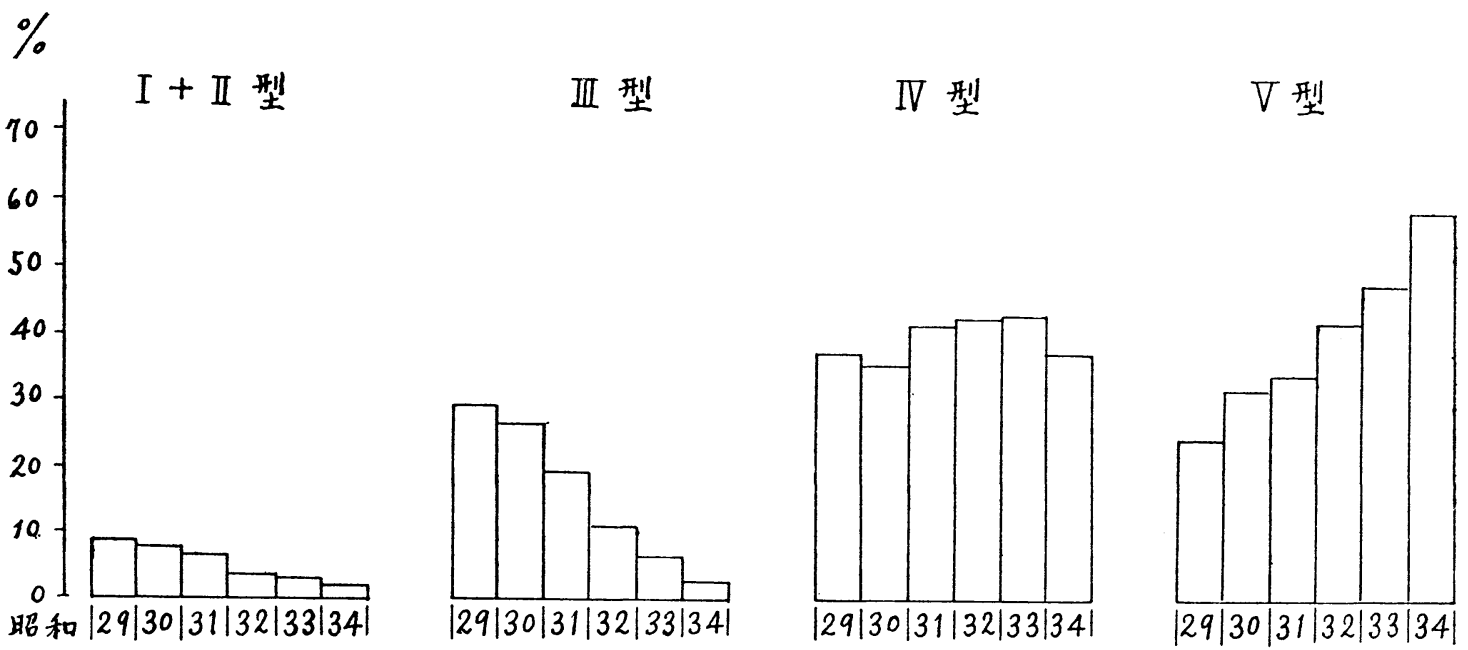

$$
\begin{aligned}
& \text { pl. 昭29. } 1(0.4 \%) \\
& \text { "32. } 1(0.3 \%) \\
& \text { "33. } 1(0.3 \%)
\end{aligned}
$$

IV 型

$\nabla$ 型

III 型

$$
\begin{array}{rll}
\text { op. } & \text { 昭 } 32.1 & (0.3 \%) \\
\text { " } 33.1+(2) & (") \\
\text { " } 34.2+(2) & (0.6 \%)
\end{array}
$$

表10 結核による死亡率（対全死亡）

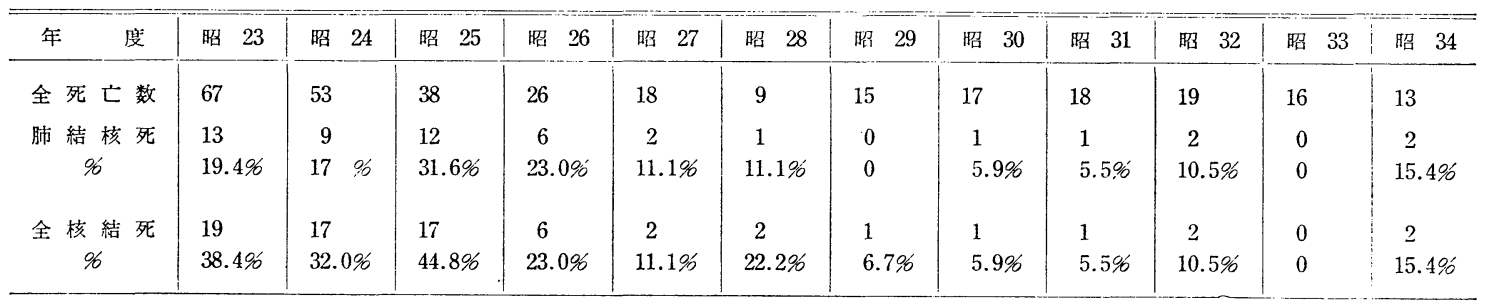




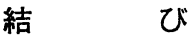

多磨全生園における在園者の昭和 23 年 略和 34 年の結 核に関する年次検診成績を検討して，次の如き結果をみ た。

1）有所見率は次第に增加し, 昭和 29 年 $20.5 \% \rightarrow$ 略和 34 年 29.4 \%。゙́でる。有病率昭和 23 年 $13.3 \%$, 昭 和 32 年 $16.2 \%$ で，乙の間を上下し增減はあまり著しくないが， 次後は着実に減少の傾向で昭和 34 年 $13.2 \%$ である。要医 療は昭和 29 年 $8.9 \% \rightarrow$ 昭和 34 年 $3.5 \%$ 亿減少, 排菌者は $2.5 \%$ 上り $0.5 \%$ (対在園者)へと減少した。

2）男子は有病率, 要医療共に女子より多く, 年令別 では20才以下は少いか又は全く無い. 最む高率の年令層 は昭和 $29 \sim 31$ 年50〜 59才であるが，昭和 $32 \sim 34$ 年は 60 才 以上の層で高年に傾いている。

3）結核管理区分及び日本結核病学会分類による結核 の病状, 活動性の推移では顕著な軽快が見られた。

4）新入園者の有病率は在園者之ほぼ同様であるが, 要医療の割合は明らかに高い。結核要指導のうち $40.3 \%$ が要医療のAである。(各年度平均)

5）新発見の要指導, 要医療の割合は減少の傾向にあ る。

6）肺結核による死亡率は昭和 27 年以降著明に減少し ている。

7）日本の結核実態調查昭和 28 年亡本園患者の昭和 29 年の検䛦成績とを比較して, 要指導 (有病率) 及び要医 療の敖合は，年令階級別に検討して，20才以下を除いた 他の各年令層に㧈いて, 要指導及び要医療共に後者は前 者の1.5〜2倍を示し, 癩の結核は明らかに一般より高率
であるととを認めた。

実態調査昭和 28 年 $\rightarrow$ 昭和 33 年の要指導の推移は $5.9 \rightarrow$ $4.7 \%$ で本園患者は昭 $29 \rightarrow 35$ 年の推移は $15.8 \rightarrow 13.2 \%$ で ある。要医療の推移は一般は $3.1 \% \rightarrow 3.2 \%$ で減少はない が, 本園患者では昭和 29 年 $\rightarrow$ 昭和 34 年の, 同様 5 年後の推 移は $8.9 \% \rightarrow 3.5 \%$ でなりの減少を示し，年令階級別に みても，若年層を除き一般よりは反対低率となつて, その減少の著明な事を示している。即ち結核管理の効果 を示すむのであろう。

擱管に臨み本研究について終始御指導を賜わりました 結核予防会結核研究所集団検診課長島尾忠男先生並びに 資料を賜わり御鞭鞋御教示いただきました本園立川昇先 生に深く感謝の意を表します。

本研究は第 33 回日本瀨学会総会においてその一部を演 述した。

\section{文献}

1）小池昌四郎：癩患者の結核症について，第 1 報 及び第 2 報), 結核予防会研究業績, 1, (1), 44 58(1951)

2）隈部英雄：日本に於ける結核の現状，P . 68 69, $76,79 \sim 81$ (1955)

3）財団此人結核予防会：結核実態調查，III，55,70, 75,81 (1960)

4）島尾忠男：管理に必要な活動性分類，結核研究の 進歩, 27, 5 11 (1959)

5）堂野前維摩郷（日本結核病学会分類委員会）：日 本結核病学会の肺結核症 X線分類, 結核文献 の 抄録 速 報, 10，5，312（1959） 